\title{
FEEDING PATTERN OF Salminus maxillosus (PISCES, CHARACIDAE) AT CACHOEIRA DAS EMAS, MOGI-GUAÇU RIVER (SÃO PAULO STATE, SOUTHEAST BRAZIL)
}

\author{
ESTEVES, K. E. and PINTO LÔBO, A. V. \\ Instituto de Pesca, Secretaria da Agricultura e Abastecimento do Estado de São Paulo, Av. Francisco Matarazzo, \\ 455, CEP 05001-900, São Paulo, Brazil \\ Correspondence to: Katharina Eichbaum Esteves, Instituto de Pesca, Secretaria da Agricultura e Abastecimento do \\ Estado de São Paulo, Av. Francisco Matarazzo, 455, CEP 05001-900, São Paulo, Brazil, e-mail: \\ kesteves@uol.com.br \\ Received January 21, 2000 - Accepted May 16, 2000 - Distributed May 31, 2001
}

(With 8 figures)

\begin{abstract}
Diet of 364 specimens of the dourado (Salminus maxillosus) was studied monthly at Cachoeira das Emas from November/1996 to May/1998, considered the breeding ground of this and other migrant fishes of Mogi-Guaçu River. Only adults were found at this site, and diet consisted exclusively of fish, with predominance of Leporinus sp. Seasonal variation in feeding activity was highest during some months of the rainy and hot season (September-December), when fish composition and number of prey species consumed also changed. These modifications were primarily attributed to an increase in food availability at the site of study during the rainy season, once most of the migrant species, including small Characidae concentrate there at this time of year. Apparently diet shifts, prey availability and rainfall are intimately related, representing a combination of factors that may account for the observed patterns of resource exploitation.
\end{abstract}

Key words: Salminus maxillosus, feeding, Mogi-Guaçu River, prey availability.

\section{RESUMO}

Padrão de alimentação de Salminus maxillosus (Pisces, Characidae) em Cachoeira das Emas, Rio Mogi-Guaçu (Estado de São Paulo, Sudeste do Brasil)

A dieta de 364 exemplares do dourado (Salminus maxillosus) foi estudada mensalmente na região denominada Cachoeira das Emas de novembro/1996 a maio/1998, local considerado o lar de reprodução desta e de outras espécies migratórias do Rio Mogi-Guaçu. Foram capturados apenas adultos, sendo a dieta composta exclusivamente por peixes com predominância de Leporinus sp. Foi observada variação sazonal da atividade alimentar, que foi maior na estação quente e chuvosa (setembro a dezembro), época na qual a composição e o número de presas consumidas foram distintas. Essas mudanças foram basicamente atribuídas a um aumento da disponibilidade de presas no local de estudo durante o período chuvoso, visto que a maioria das espécies migratórias, incluindo pequenos Characidae, se concentra aí nessa época. Aparentemente, as mudanças na dieta de $S$. maxillosus, a disponibilidade de presas e a pluviosidade estão intimamente correlacionadas, representando uma combinação de fatores que explicam os padrões de exploração de recursos aqui observados.

Palavras-chave: Salminus maxillosus, alimentação, Rio Mogi-Guaçu, disponibilidade de presas.

\section{INTRODUCTION}

The dourado, a large food and sport fish salmon like in appearance, is found from de la Plata to Amazonas, being a regular migrant in the lower and middle Paraná River and in the Pilcomayo and upper Paraná (Lowe McConnell, 1975). In the Mogi-Guaçu River (São Paulo State), the spawning 
runs for this and other commercial species have been described by Schubart (1943, 1953, 1954) and Godoy (1975) during a ten year period. Salminus maxillosus, Valenciennes, 1840, and several other commercial species showed similar characteristics with single seasonal movements to and from a down river feeding zone and an upper breeding zone, covering distances totalling 1,2001,400 km/year (Godoy, 1975). These migrations involve three rivers of the upper Paraná River Basin: the Mogi-Guaçu, Pardo and Rio Grande. Breeding grounds for most of the migrant fishes are in the upper Mogi-Guaçu, while the feeding, growing and fattening areas are in the middle of Rio Grande (Godoy, 1967). At the breeding ground (Cachoeira das Emas), during the start of the rainy season (December-January), thousands of fishes concentrate, trying to move up the fish ladder alongside a hydroelectric dam.

Since the end of the studies of Godoy (1975) on the ecology of the fish species of Mogi-Guaçu River in 1963, very little information about $S$. maxillosus and other commercial fish species have been obtained. Considering that $S$. maxillosus contributes with a high percentage of fish biomass for the fisheries of this river, and that pollution sources along the basin, corresponding to alcohol, sugar, paper and cellulose industries, as well as domestic sewage (Cetesb, 1982) have increased, these alterations may have affected fish populations in the last years. As part of a larger project that aimed to study the population dynamics of this species, here we examined the feeding ecology of Salminus maxillosus during the period of November/1996 to May/1998, with the aim of understanding the influence of fish size as well as seasonal influences on diet composition.

\section{MATERIAL AND METHODS}

\section{Study area}

Mogi-Guaçu River headwaters rise in the State of Minas Gerais at an altitude of 1,650 m, running towards São Paulo State, where it covers a distance of $377.5 \mathrm{~km}$. The whole basin has been estimated as being 17,460 $\mathrm{km}^{2}$ (Schubart, 1953), with a drainage area of $3,420 \mathrm{~km}^{2}$.

Cachoeira das Emas is situated at $21^{\circ} 58^{\prime} \mathrm{S}$ and $47^{\circ} 26^{\prime} \mathrm{W}$, at an altitude of $560 \mathrm{~m}$ at the $\mathrm{km}$
255 of the river. At this site, where the river is $80 \mathrm{~m}$ wide and 2 to $3 \mathrm{~m}$ deep, a fish ladder alongside a hydroelectric dam, allows fishes to move river up (Fig. 1a, b).

According to the international system of Köeppen, the predominant climate in this region is Cwa (hot climate with a dry winter), with a mean air temperature of $22^{\circ} \mathrm{C}$ in the hot season, and $18^{\circ} \mathrm{C}$ in the cold season. The mean annual rainfall is between 1,100 and 1,200 $\mathrm{mm}$. Two predominant periods have been described for the region: a humid one, at the hot months (October to March), with the highest rainfall, and a dry and cold one (AprilSeptember).

Considering the monthly rainfall obtained for the period of study, Fig. 2 shows that although a similar pattern occurred between years, maximum values occurred at different months of the hot period in the different years.

\section{Field work and stomach content analysis}

Fishes were collected monthly at Cachoeira das Emas, at a region just below the dam, where rocks are abundant, and water speed is high. Cast nets of different mesh sizes $(3,6,8,12 \mathrm{~cm})$ were used during the day, and fishes preserved in ice until measured and weighed in the laboratory. Specimens were measured for total length to the nearest $0.1 \mathrm{~mm}$ (all lengths are reported hereafter as $\mathrm{Lt})$.

At the laboratory stomachs were weighed, and those containing whole preys immediately oppened, and the prey identified, measured and weighed. Stomachs were preserved in formalin $10 \%$ until more detailed analysis in the laboratory. Gut contents were examined under a stereomicroscope $(10 \mathrm{x})$ and food items identified to the most detailed possible level and then counted, weighed and measured.

Unidentified items were basically grouped into "Fish parts", when prey had undergone some digestion, but was not identifiable, and "Organic matter" when digestion was advanced and origin of item was indistinguishable.

Frequency of occurrence and points method (Hynes, 1950) were employed, as well as the gravimetric method. For the points method, the total area of the food items was considered the total volume $(100 \%)$. 

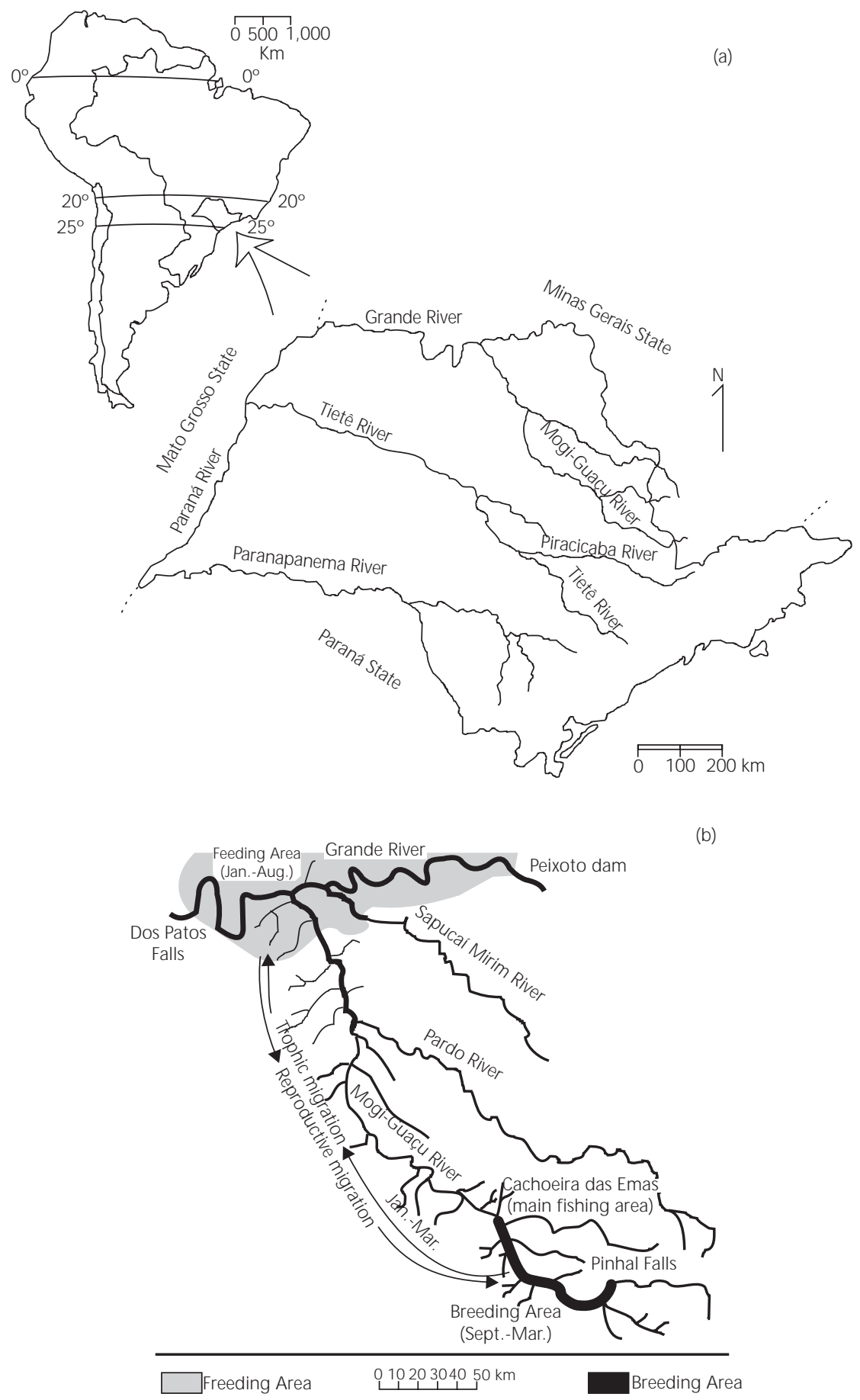

Fig. 1 - a - Location of Mogi-Guaçu River in São Paulo State, Brazil; and $\mathbf{b}$ - and migration of fish within the MogiPardo-Grande river system (after Godoy, 1975). 


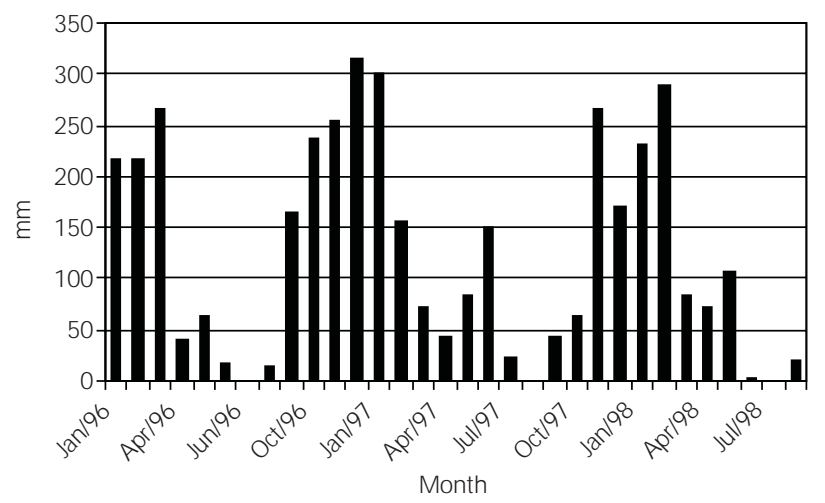

Fig. 2 - Total monthly rainfall obtained at the municipality of Pirassununga for the period of January/96 to August/98. formula:

Calculations were made according to the

$$
P_{i j}=\frac{\sum_{x=1}^{N} P_{i x}}{N_{j}}
$$

where $\mathrm{P}_{\mathrm{ix}}$ is the proportion by volume of item $\mathrm{i}$ in the gut of the individual $x$ and $N_{j}$ is the number of individuals of species $\mathrm{j}$.

For monthly determinations of feeding activity, the Repletion Index, considered the relation between stomach weight/fish weight was calculated. Mean number of prey/predator was calculated considering only those predators that contained identifiable prey.

\section{RESULTS}

Three hundred and sixty four specimens were analised during the period of August/96 to June/ 97 , with individuals varying between 28.3 and $87.0 \mathrm{~cm}$ of total length. Fig. 3 shows that the most frequent size classes were those of $49.0-56.0 \mathrm{~cm}$ and $56.0-63.0 \mathrm{~cm}$. Although a defined pattern of size frequency distribution was not observed, results showed that at some dry season months (May, June, August) as well as in December 1997, a higher amplitude of size of the collected specimens occurred at the sampling site.

Considering the variation in stomach repletion, it was observed that $72.25 \%$ of the individuals presented empty stomachs. Fig. 4 shows however that seasonal variation in feeding activity occurred during the period, with highest values at the rainy season, mainly from October to December. At the dry season most of the specimens had empty stomachs, resulting in a low Repletion Index.

Organic matter and fish were the main components of the diet of $S$. maxillosus, with only three fish species comprising its diet. Leporinus sp. was the most important species consumed, attaining frequencies near $100 \%$ (gravimetric method), and near $80 \%$ (points method) (Fig. 5). This species was consumed both during the dry and wet seasons. During the wet period, its relative frequency however lowered, once other species as Astyanax bimaculatus, Steindachnerina insculpta and Astyanax sp. were added to the diet. Considering diet variation according to size, Fig. 6 shows that "fish parts" were dominant in all size classes (60\%-100\%), followed by "fish", which was more frequent at higher size classes. Identifiable prey were more commonly found from the size class of 42.0$49.0 \mathrm{~cm}$ onwards, where smaller prey as Astyanax and Steindachnerina were more frequent.

From the dispersal diagram which shows the relation between prey and predator lengths (Fig. 8) a weak correlation was found $\left(r^{2}=0.11\right)$, indicating no difference in the size of prey ingested by predators of different size. Considering however the mean number of prey consumed by $S$. maxillosus that contained identifiable prey, a variation was observed especially during the rainy season of 1997 (Fig. 7), when the number of prey per predator increased. 

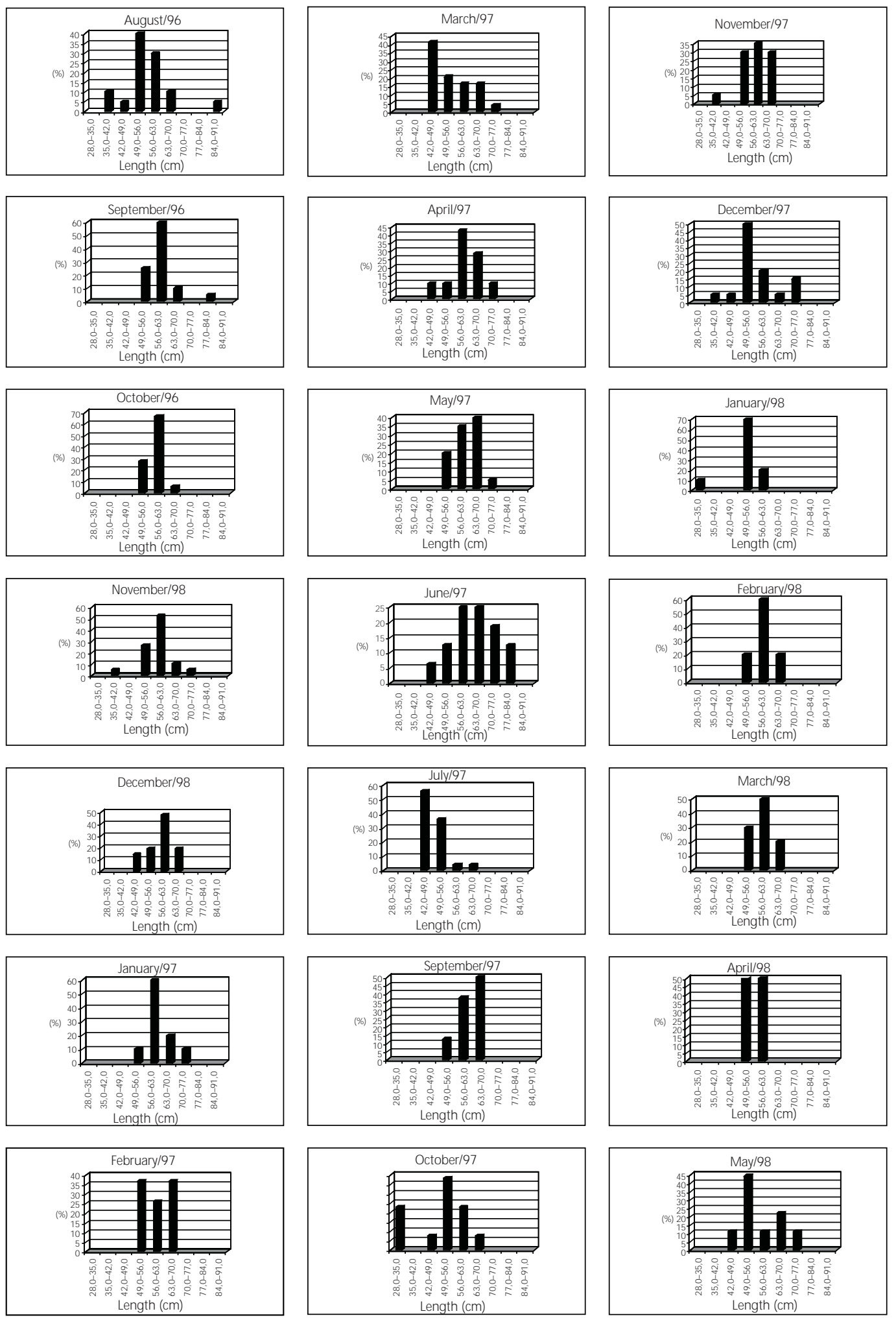

Fig. 3 - Size frequency distribution of the specimens of S. maxillosus collected with cast nets at Cachoeira das Emas from January/96 to June/98. 


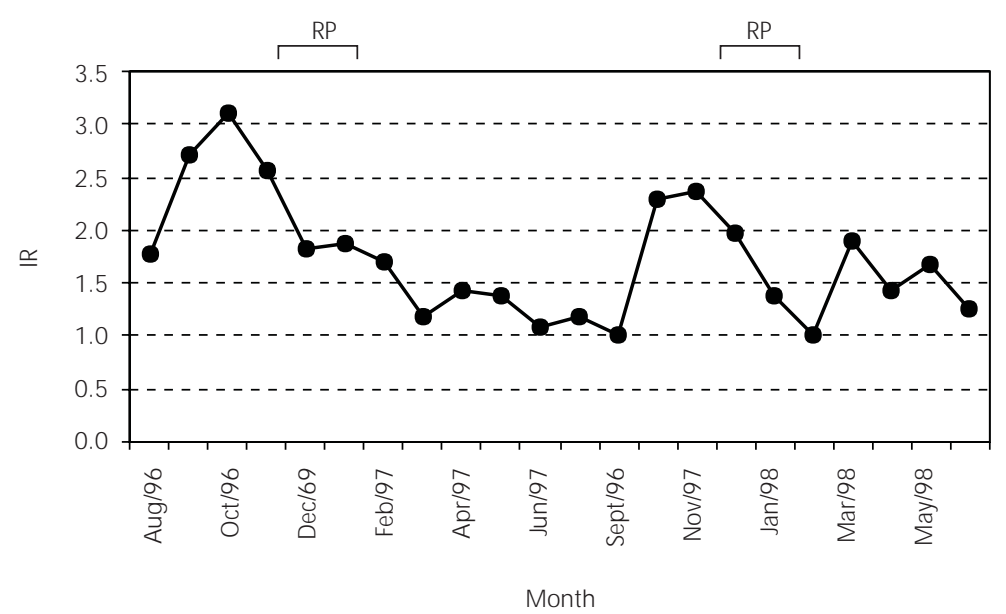

Fig. 4 - Seasonal variation of the Repletion Index of S. maxillosus during the period of January/96 to June/98, indicating reproductive period (RP).

\section{DISCUSSION}

In order to understand the results obtained in this study it is important to consider the role of the sampling station (Cachoeira das Emas) in the biology of the fish populations of Mogi-Guaçu River. As largely described by the studies of Godoy (1967) for the system of Mogi-Pardo-Grande rivers, when temperature and rains start to increase, water level rises (September-December) initiating spawning runs, known locally as "piracema". At this time, Characoids and Siluroids migrate upstream to breed, until they reach Cachoeira das Emas, considered the greatest fishery center of MogiGuaçu River, and contributing with $50 \%$ of the total catch of this river. After spawning, fishes move downstream, until they reach fattening areas in the middle Grande River.

According to Godoy (1975), the male reproduces at the second year of life, at a size between 24.0 and $26.0 \mathrm{~cm}$ and the female at the third year of life, at a size between 30.0 and $38.0 \mathrm{~cm}$.

Although attempts were made to find the young of S. maxillosus at different oxbow lakes located in the floodplain of Mogi-Guaçu River as well as in the main river channel upstream Cachoeira das Emas, no young individuals were found. Thus, our results indicated that only adults were sampled during the period of study and that part of the adult population stays at Cachoeira das Emas during the whole year. Considering the food composition of $S$. maxillosus our results showed that this species was essentially piscivorous, consuming exclusively fishes of three species, but showing preference for Leporinus sp. Almeida et al. (1997) found that this and other predatory species in floodplains of the Paraná River completed its diet with insects, crustaceans and some grasses, consuming 11 diferent fish species. The low diversity of food ingested by $S$. maxillosus in our study, probably reflects not only the environment, poor in macrophytes and associated insects as well as in fish species during most of the year, but also the fact that young specimens, that may consume insects (Morais Filho \& Schubart, 1955) were not analised.

The high number of empty stomachs found for $S$. maxillosus, seems to be common among piscivorous species as shown for Hoplias malabaricus (Loureiro \& Hahn, 1996) and several others from the Venezuelan llanos (Winemiller, 1989). According to this author, the feeding rate of large piscivores is often relatively low due to the time required for digestion of massive prey items prior to initiation of a new feeding bout.

The Repletion Index has been used to describe variations in the feeding activity (Almeida, 1980), and in general the reduction in food intake in the tropical region has been correlated with the dry season, that represents a period of low food offer (Prejs \& Prejs, 1987). 
(a)

(\%)

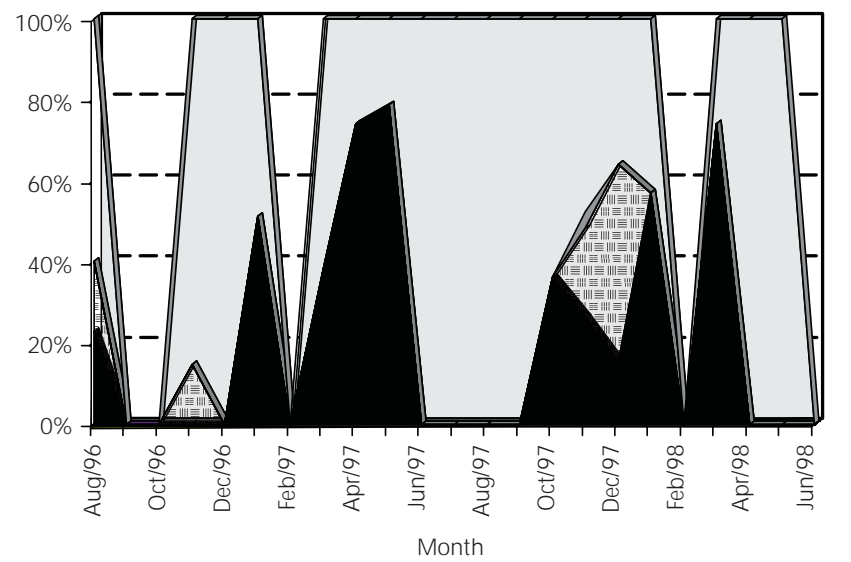

$\square$ Organic matter

$\square$ A. bimaculatus

国 Astyanax sp.

Leporinus sp.

(b)

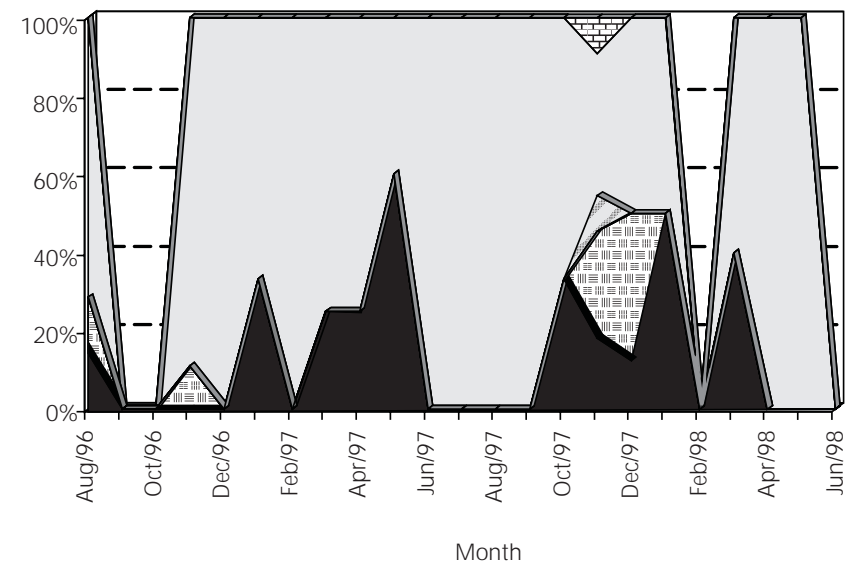

国 Steindachnerina insculpta

$\square$ Organic matter

A. bimaculatus

国 Astyanax sp.

- Leporinus sp.

(c)

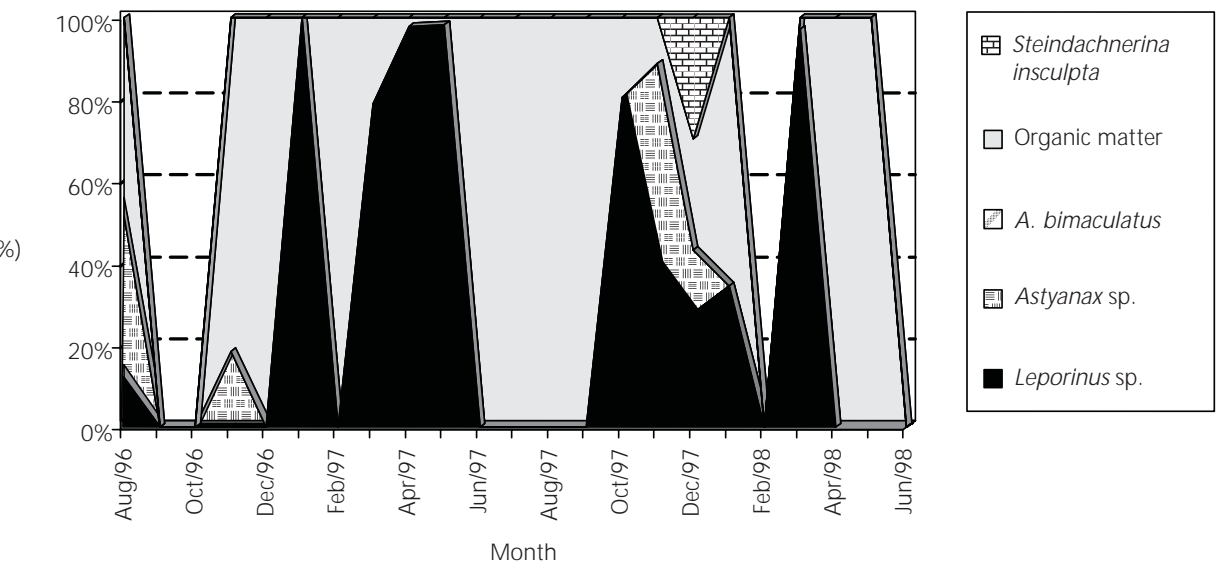

Fig. 5 - a - Relative frequency of food items analised by the Points; b - Frequency of Occurrence; and c - Gravimetrical methods. 
(a)

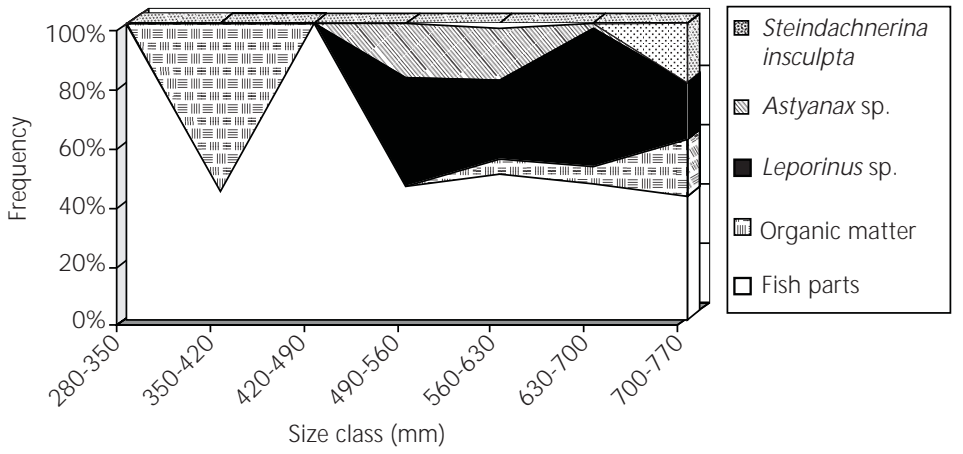

(b)

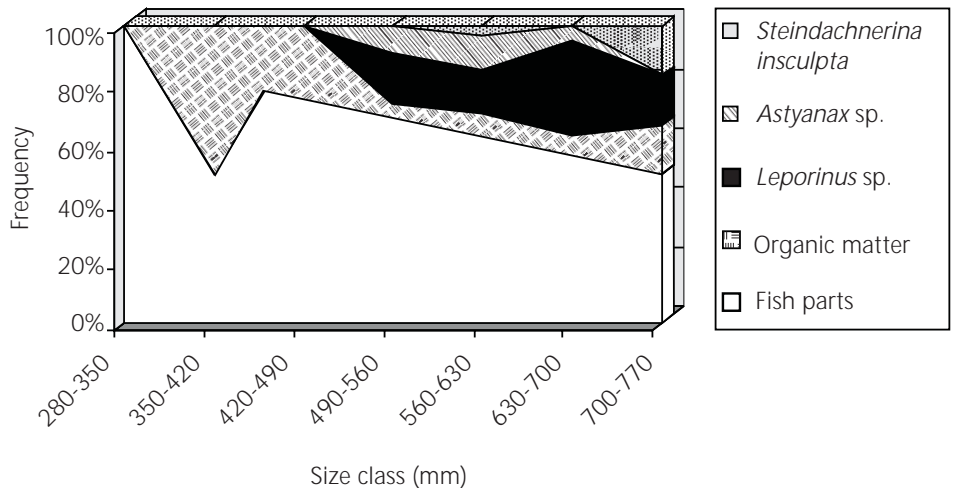

Fig. 6 - Major diet shifts according to fish size. a - Points method; and b - Frequency of Occurrence.

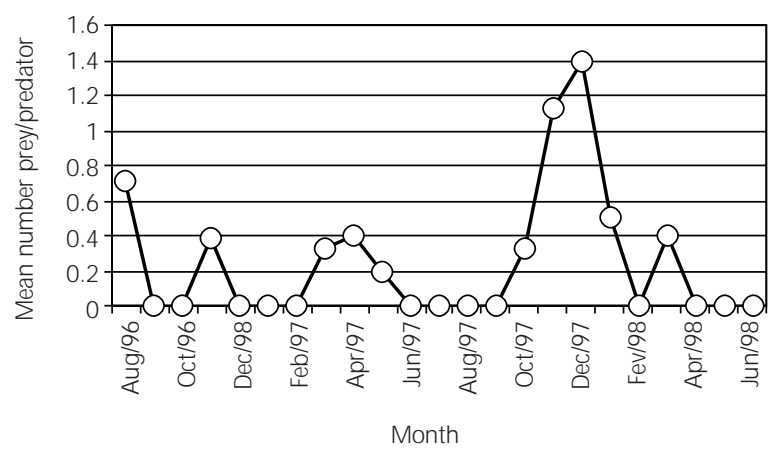

Fig. 7 - Mean number prey/predator for specimens with whole prey in stomachs.

Our results, in fact, showed that feeding activity was lowest in the dry season, increasing during the hot and rainy months, especially in November and December.

Although several factors like size and type of prey, microhabitat and activity hours of the predator and prey influence the food intake, availability has been considered predominant in the fishes diets (Wootton, 1990). Even though we do not have data about the availability of prey in the environment, the well known migration studies of Godoy (1967) for the several species of Mogi- 
Guaçu River, indicate that at the rainy season thousand of these migrating fish concentrate at Cachoeira das Emas. Thus, it seems that availability of prey during this time of the year is increased at the site of study, supporting our results that indicated higher feeding activity for this period.

Not only the activity changed at this time of year, but also the kinds of prey eaten as well as the number of prey taken by individual predators. Thus, especially from October 1997 to January 1998, S. maxillosus included Astyanax and Steindachnerina insculpta in its diet, with five to six individuals being found in the same predator in several occasions. Gealh \& Hahn (1998) reported that the smaller specimens of the piscivorous Oligosarcus longirostris of Salto Segredo Reservoir (Brazil) tend to include larger prey relative to its size than larger predators, that usually consume more than one individual prey.

Although very little is known about the way S. maxillosus capture its prey, and considering that the size of $S$. maxillosus here studied did not include larger specimens at the months of higher food availability, the results suggest that the relationship between predator and prey here observed, follows the functional response curve as shown by Wootton (1990), where as the density of prey increases, the number attacked increases. This curve is asymptotic, mainly because fish become satiated and the predatory fishes take up some of the available time capturing and handling each prey.

Prey size has been emphasized as one of the factors that influence food intake. Several studies show that bigger fishes may profitably take food from a wide range of sizes, as was the case in this study. This tendency was also observed by Almeida et al. (1997) who reported that for the five piscivorous fishes studied in the Paraná River floodplain, small prey were preyed upon by all fish up to those of $45.0 \mathrm{~cm}$ in length. Loureiro \& Hahn (1996) found that for Hoplias malabaricus bigger specimens tended to include smaller prey, suggesting that with growth a wider range of prey are captured.

Results concerning diet according to fish size, cannot be considered as an ontogenetic variation, once samples did not include young specimens. However results showed that from $28.0 \mathrm{~cm}$ onwards $S$. maxillosus feeds exclusively on fish and that small Characidae as Astyanax and Steindachnerina occur at higher size classes. Apparently diet shifts, prey availability and rainfall in this case are intimately related, representing a combination of factors that may account for the observed patterns of resource exploitation.

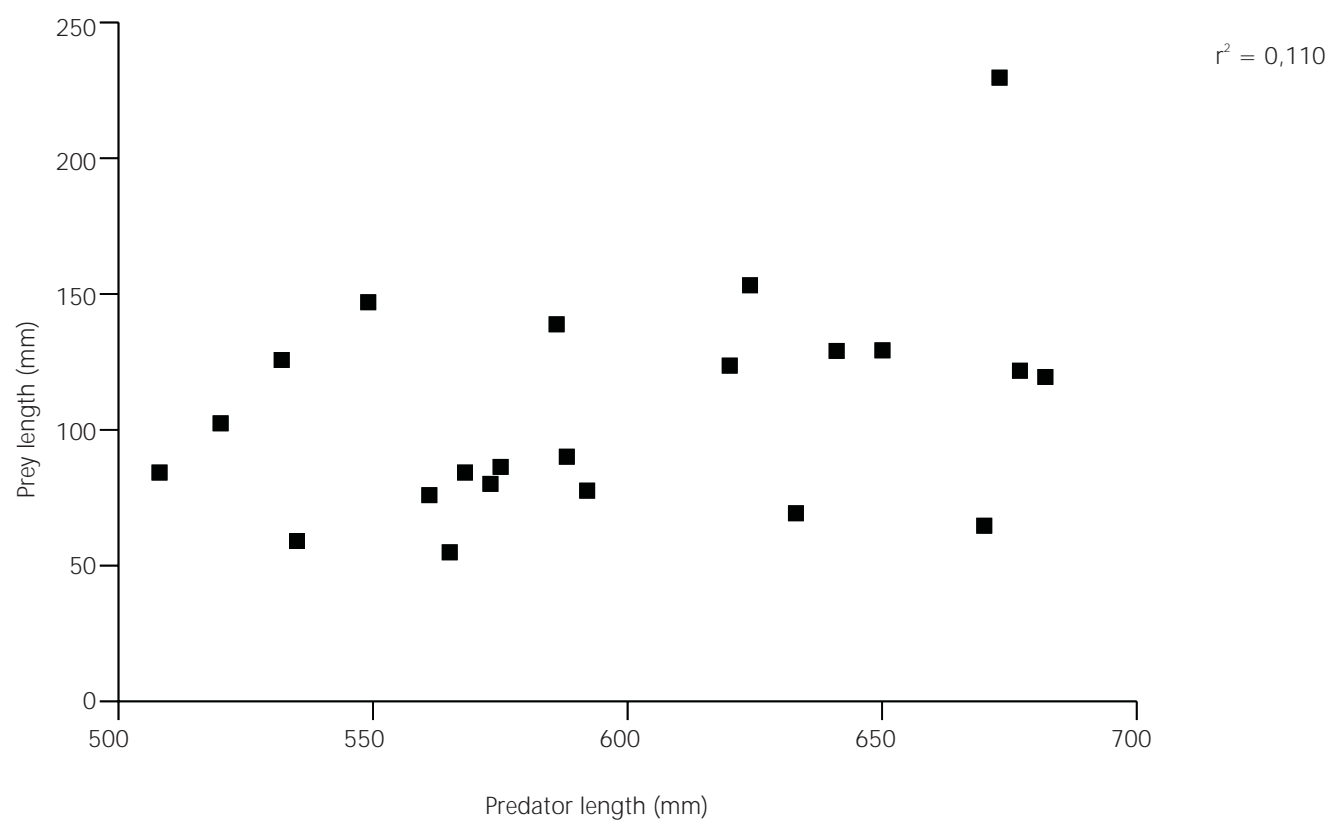

Fig. 8 - Dispersal diagram of the prey and predator length values. 
Acknowledgments - We thank CNPq for the grants provided for this project (Proc. n. 520546/96-2); the "Núcleo de Biologia de Peixes Fluvias de Pirassununga" (Instituto de Pesca) for facilities, and the fishermen Jair Donizette Mazaferro and Roberto Zolio ("Cobrinha") for collection of data in the field. We also thank Geraldo Barbieri for valuable discussions and reading of the manuscript.

\section{REFERENCES}

ALMEIDA, R. G., 1980, Aspectos taxonômicos e hábitos alimentares de três espécies de Triportheus (Pisces, Characoidei, Characidae) do lago Castanho, Manaus, Amazonas. Instituto Nacional de Pesquisas da Amazônia, Manaus.

ALMEIDA, V. L. L., HAHN, N. S. \& VAZZOLER, A. E. A. de M., 1997, Feeding patterns in five predatory fishes of the high Paraná River floodplain (PR, Brazil). Ecology of Freshwater Fish, 6: 123-133.

CETESB, 1982, Piscicultura e qualidade das águas do Estado de São Paulo. São Paulo, 131p.

GEALH, A. M. \& HAHN, N. S., 1998, Alimentação de Oligosarcus longirostris Menezes \& Gèry (Osteichthyes, Acestrorhynchinae) do Reservatório de Salto Segredo, Paraná, Brasil. Revta. Brasil. Zool., 15(4): 985-993.

GODOY, M. P., 1967, Dez anos de observações sobre periodicidade migratória de peixes do Rio Mogi-Guaçu. Rev. Brasil. Biol., 27(1): 1-12.

GODOY, M. P., 1975, Peixes do Brasil: Subordem Characoidei. Franciscana, Piracicaba.

HYNES, H. B. N., 1950, The food of fresh-water sticklebacks (Gasterosteus aculeatus and Pygosteus pungitius), with a review of methods used in the studies of the food of fishes. J. Anim. Ecology, 19: 36-58.
LOUREIRO, V. E. \& HAHN, N. S., 1996, Dieta e atividade alimentar da traíra, Hoplias malabaricus (Bloch, 1794) (Osteichthyes, Erythrinidae), nos primeiros anos de formação do Reservatório de Segredo, PR. Acta Limnologica Brasiliensia, 8: 195-205.

LOWE-McCONNELL, R. H., 1975, Fish communities in tropical fresh-waters: their distribution, ecology and evolution. Longman, London.

MORAIS FILHO, M. B. \& SCHUBART, O., 1955 , Contribuição ao estudo da pesca no Rio Piracicaba. Escola Superior de Agricultura Luiz de Queiroz, III, Piracicaba, 76p.

PREJS, A. \& PREJS, K., 1987, Feeding of tropical freshwater fishes: seasonality in resource availability and resource use. Oecologia, 71: 397-404.

SCHUBART, O., 1943, A pesca na Cachoeira das Emas do Rio Mogi-Guaçu durante a piracema de 1942-1943. Bolm. Ind. Anim N. S., 6: 93-116.

SCHUBART, O., 1953, Ubereinen subtropischen Fluss Brasiliens, den Mogi-Guaçu, insbesondere seine physikalischen Bedingungen wie Wasserstand, temperatur und sichtiefe. Arch. Hydrobiol., 48: 350-430.

SCHUBART, O., 1954, A piracema no Rio Mogi-Guaçu (Estado de São Paulo). Dusenia, 5(1): 49-59.

WINEMILLER, K. O., 1989, Ontogenetic diet shifts and resource partitioning among piscivorous fishes in the Venezuelan ilanos. Env. Biol. Fishes, 26: 177-199.

WOOTTON, R. J., 1990, Ecology of teleost fishes. Chapman and Hall, London, 404p. 